\title{
THE RELATIONSHIP BETWEEN JOB SATISFACTION AND INDIVIDUAL PERFORMANCE OF IT EMPLOYEES
}

\author{
Irina Yanchovska ${ }^{1}$
}

\begin{abstract}
:
Purpose - The main purpose of this research paper is to investigate the correlation between job satisfaction of employees in the IT sector and their personal performance. Additionally, the study examines the overall level of employee satisfaction, as well as if job satisfaction levels differ significantly among the studied demographic groups.

Design/methodology/approach - The research is based on quantitative analysis of data collected through a questionnaire containing answers of 126 international respondents from over 25 different IT companies. The research methods used are onedimensional methods for preliminary analysis, Cronbach alpha for reliability and consistency, one-way ANOVA for mean values comparison and correlation analysis for examining relationships.

Findings - The findings show a moderate statistically significant correlation between job satisfaction and employees' personal performance, which is bidirectional as influence and presumably depends on other variables like work engagement, motivation, stress or exhaustion, which were not examined in the current study. Additionally, most of the employees in the researched sample define themselves as satisfied with their jobs. Statistically significant variation of the mean job satisfaction levels was observed in two of the examined demographic variables - gender and years in the current position.

Practical implications - The research results can be beneficial for different organizations since job satisfaction is important for employees' long-term retention, for increasing their commitment and loyalty towards the organization, as well as for the creation of a motivating and productive work environment. Employees' job satisfaction and their personal performance should always be considered main organizational values and key for achieving excellent business results and market leadership.

Originality/value - The results of the current research are important for validating the position of these researchers, who claim that a positive correlation between an employees' job satisfaction and their personal performance in the workplace exists and should not be neglected. Additionally, it contributes towards a better understanding of job satisfaction among IT employees.
\end{abstract}

JEL Classification Numbers: J28, M12, M54, DOI: https://doi.org/10.12955/peb.v2.267

Keywords: job satisfaction, individual performance, IT employees, IT industry

\section{Introduction}

Employees' job satisfaction affects the prosperity and effectiveness of every business organization, and due to its importance, it is subject to numerous studies. Employees' performance is another area of high interest among scholars and business owners since the human resource is perceived as the most important driving force in the business world. Even if the association between job satisfaction and individual performance has been examined by numerous authors for many years, scholars researching this relationship still obtain controversial and unsatisfactory results.

The business world is witnessing an unprecedented talent turnover caused by the desire of employees to achieve their personal and professional goals. This creates a growing level of concern among companies that find it increasingly difficult to retain their long-term talented and highly qualified employees (Valaei $\&$ Rezaei, 2016). The focus on highly skilled employees and their long-term retention and development turns job satisfaction into one of the most strategic topics for IT companies in Bulgaria and around the world. Satisfaction and motivation of employees are mandatory elements for today's business as a key factor that distinguishes successful companies (Ćulibrk et al., 2018). For this reason, internal programs and procedures that focus on improving job satisfaction factors in the workplace can be beneficial for companies that want to retain and further develop their highly qualified employees.

People working in the IT sector can be considered a unique case since some of the factors affecting their job satisfaction are industry-specific. This can be partially explained by the fact that IT companies employ a higher number of qualified personnel, offer better working conditions, many opportunities for training and professional development, as well as a large number of social benefits and flexible working conditions that are not typical for many other industries.

The study is based on quantitative analysis, and its main goal is to examine whether there is a connection between job satisfaction and the individual performance of IT employees. The main research objectives are to measure the level of satisfaction among selected employees, to explore how employees determine their own performance and to investigate the relationship between the two variables. Additionally, the

\footnotetext{
${ }^{1}$ Sofia University "St. Kliment Ohridski ”, Faculty of Economics and Business Administration, iyanchovska@gmail.com
} 
study aims to examine if job satisfaction levels differ significantly between different employee groups, based on four demographic factors - gender, age, level of education and years in the current position.

The object of the research are employees in the IT sector, and the subject of the study is the way they perceive their personal satisfaction, measured on the basis of five factors, as well as their personal performance, based on the self-evaluation of the subject group.

\section{Job Satisfaction}

Many contemporary business owners and leaders recognize the role of employees as a major success factor for organizations. Some of the most successful companies today are turning significant attention to the satisfaction of their employees, which does not only refer to ensuring acceptable or even excellent working conditions but also includes the creation of a healthy environment for balance between employees' professional and personal lives (Moro et al., 2020).

In the 1930s, Robert Hoppock was one of the first researchers to consider employee satisfaction as a complex and balanced experience associated with various influencing factors. According to him, satisfaction with work is the combination of psychological and physiological factors and conditions of the environment that make the individual define oneself as truly satisfied with one's work.

More than 80 years ago, Hoppock realized and analysed the multi-layered nature of employees' satisfaction and the fact that it cannot be influenced by only one factor. Being a psychological characteristic of the individual, job satisfaction depends on the person's world view, feelings and emotions (psychological factors), the factors of the external environment, which the employee perceives important, as well as on purely physiological factors that include different conditions of the workplace.

After many modifications and additions, job satisfaction becomes a cumulative definition of people's perception of their work experience, which also affects their overall attitude towards life and has a significant effect on their health, happiness and self-esteem (Crespi-Vallbona \& Mascarilla-Miró, 2018). Such an extensive definition is not surprising because it is practically impossible to separate job satisfaction and people's overall attitude towards their lives.

Satisfied employees have a better sense of the work environment and are much more likely to maintain higher levels of motivation (Crespi-Vallbona \& Mascarilla-Miró, 2018), which affects people's desire to do more than expected, to be more ambitious and willing to take more initiatives.

Generally, a person's overall attitude towards life, professional or personal, has a great impact on one's environment. Positive emotions, kindness and a friendly attitude serve as a good example for others family members, friends or colleagues. Thus, a satisfied employee can significantly influence corporate culture and the working environment throughout the organization. In addition, it is less likely a satisfied employee will leave the company or be absent without a serious reason, which positively affects the long-term retention of staff.

Many authors observe a proportional relationship between job dissatisfaction and a number of negative traits in employee behaviour, such as higher turnover and absenteeism and even a deliberate desire to harm the organization (Firth et al., 2004; Mount et al., 2006; Bednarska \& Szczyt, 2015).

An employee's dissatisfaction can also affect other aspects of work life. It can lead to higher levels of stress, extreme emotional exhaustion, burnout, low productivity and lack of commitment. Dissatisfied employees are often careless and ignorant about their obligations, customer requirements or deadlines; their low desire to work leads to lethargy and reduced personal productivity. Such employees perform far below their potential, which can become a serious problem for companies.

Based on the literature review, it can be concluded that job satisfaction creates favourable conditions for higher commitment, enthusiasm, positive attitude and attachment to the organization, higher productivity, motivation and willingness to take initiatives and achieve higher results (Judge et al., 2001; Kamalanabhan et al., 2009; Valaei \& Rezaei, 2016; Ismail \& Razak, 2016; Martins Abelha et al., 2018; Taba, 2018), whereas, an overall dissatisfaction with work can have a negative impact on commitment, quality of work, desire to take new tasks and responsibilities and can lead to higher levels of stress, delays and absences, low productivity and burnout (George \& Zakkariya, 2015; Huang \& Wang, 2019). 


\section{Individual Performance}

Employees' individual performance is the second construct that is represented in the present study. Organizational goals and overall business performance should not be perceived as different or independent of the individual employee contribution. Being essential building blocks of the organization, employees and their work performance directly affect business results. For this reason, the individual performance of employees can be considered a vital element for the overall performance of organizations.

Generally, individual performance in the workplace can be defined as the aggregate value of employee contribution to the development of the organization in a certain period (Motowidlo et al., 1997). For the purpose of this study, individual performance will be expressed as the average value of some individual characteristics of employees' work - the quality of tasks performed, effectiveness, productivity, willingness to take initiatives, as well as the extent to which the employee's work brings value to the organization.

\section{Relationship between Job Satisfaction and Individual Performance}

The relationship between job satisfaction and personal performance in the workplace evokes wide interest and has been at the centre of numerous academic studies during the years. Many contemporary authors continue to study this association since it is an essential topic for human resources and management structures of many companies.

Historically, a large number of studies have been conducted to examine the level of correlation between the two concepts, but their results are inconsistent and controversial. One of the most significant studies, published in 1955 by Brayfield and Crockett, concluded that the relationship between satisfaction and performance in the workplace is not significant. This study was followed by several other influential reviews that significantly differed in their specificity, as well as the level of optimism, which they expressed in relation to the existence of a correlation between satisfaction and performance (Herzberg et al., 1957; Vroom, 1964; Locke, 1970; Schwab and Cummings, 1970). In 1988 Dennis Organ argued that the failure to establish a link between job satisfaction and personal performance in previous surveys was due to the limited definition of job performance, which was often reduced to performing a specific task. The author argued that if the concept was more broadly defined, its relationship to job satisfaction would be stronger.

On the other hand, many scholars often mention the existence of the connection between job satisfaction and personal performance in their studies. For example, according to Ostroff (1992), job satisfaction is related to the personal performance of employees and organizational outcomes. Regarding personal performance, international literature shows that it is affected by a large number of factors, among which are job satisfaction, work environment, remuneration policies etc. (Platis et al., 2015).

The ambiguity of the results of these studies is slightly surprising. At first glance, the connection between satisfaction and performance does not seem very complicated, but rather clear and logical satisfied employees should be better at performing their work duties. Nonetheless, as many studies show, this correlation turns out to be sophisticated, multi-layered and sometimes quite contradictory.

In 2001, T. Judge and J. Bono from the University of Iowa, C. Thoresen from Tulane University and G. Peyton from the University of North Dakota did a large-scale meta-analysis that examined the relationship between job satisfaction and employee performance. They used 254 published and unpublished studies, which were selected by a group of predefined criteria and examined a large sample of 54,417 individual responses of working adults. Examining at least seven different models of interaction, the authors conclude that there is a moderate positive correlation between job satisfaction and performance in the workplace $(\mathrm{r}=.30)$ (Judge et al., 2001).

\section{Research Model and Hypotheses}

The main goal of the present study is to inspect whether there is a correlation between the job satisfaction of employees in the IT industry and their personal performance. Secondly, the research aims to examine the overall level of employees' satisfaction. Additionally, considering the specific characteristics of the IT sector like the existence of diverse, international teams, focus on providing an equal opportunity, many options to grow professionally inside the organization and others, it is not expected that the 
average level of job satisfaction of IT employees will differ significantly, based on their gender, age, level of education and years in the current position.

\section{Research Hypotheses}

H1 (main research hypothesis): The job satisfaction of employees in the IT sector is positively related to their individual performance in the workplace.

$\mathrm{H} 2$ : Most IT employees in the subject group define themselves as satisfied with their work.

H3: The average job satisfaction levels of IT employees do not differ significantly, based on their gender, age, level of education and years in the current position.

\section{Research Data and Methodology}

For the purposes of the study, a questionnaire with three main parts was created. The survey was in English and contained 6 demographic and 23 specific questions. All questions were mandatory to answer, and only two of the demographic questions allowed free text entry.

The demographic part of the questionnaire collects information about gender, age, level of education, current employer, the country in which the employee works and years in the current position.

The part of the questionnaire that examines employees' overall satisfaction contains five main satisfaction factors, which were selected as the most important by employees in the IT field - pay and social benefits, career development opportunities, nature of work, work atmosphere and team spirit and dynamic working conditions. The questionnaire contains three statements to examine each factor. A sample statement from this part of the questionnaire is "I find my job useful and meaningful". The questions measuring the first four satisfaction factors are taken from Spector's Job Satisfaction Survey (1994). The three questions exploring dynamic working conditions are specially designed for the purposes of the present study. Overall, the second part contains 16 statements, assessed through a 5point Likert scale $(5=$ Strongly agree to $1=$ Strongly disagree). The first 15 questions are grouped into 5 categories corresponding to the five satisfaction factors, and the last question measures the overall satisfaction of the respondents.

The third part of the questionnaire contains five self-assessment questions that measure different elements, determining employees' overall performance - the quality of work, effectiveness, productivity, contributed organizational value and proactiveness, as well as two questions that measure the overall individual performance and the line manager's assessment. Overall, this part of the survey contains 7 questions - the first five measure the elements of personal performance and the last two - the overall performance level according to the employees and according to their line manager. A sample question is "How do you evaluate your overall productivity?" A 5-point scale (5 = Far above average to $1=$ Far below average) is used to assess the individual performance questions.

The questionnaire was distributed in January 2019 to a preselected list of 244 targeted respondents, and valid answers were received from 126 employees, which represents a significantly high response rate (51.64\%) in the given timeframe (the time provided for completing the questionnaire was one week).

The sample includes $65.9 \%$ men and $34.1 \%$ women. The largest age group are employees between 35 and 44 years, representing $41.3 \%$ of the sample; the second-largest are those between 18 and 34 years $(37.3 \%)$.

In relation to the level of education, $88.1 \%$ of the respondents have a university degree (61.9\% Master's and $26.2 \%$ Bachelor's). According to the experience in the current position, most respondents fall under the category between 0 and 3 years (43.7\%), followed by those between 4 and 7 years $(22.2 \%)$.

The respondents that took part in the survey live and work in different countries, however, the largest number of employees (72.2\%) live and work in Bulgaria. Although there are respondents that work in over 25 different companies, more than $60 \%$ of all participants work in one international IT company DXC Technology.

\section{Results and Discussions}

IBM SPSS Statistics is used for data analysis, and the applied methods are: one-dimensional models for primary analysis and testing hypothesis $2(\mathrm{H} 2)$, a one-way ANOVA for testing if the mean values of job satisfaction are significantly different in the different demographic groups and testing hypothesis $3(\mathrm{H} 3)$, Cronbach's alpha to verify the reliability and internal consistency of the questions, measuring job 
satisfaction and individual performance and to confirm the scale reliability and correlation analysis for examining relationships and verifying the main research hypothesis.

\section{One-Dimensional Models}

The initial analysis shows that, on average, the examined employees are mostly satisfied by the workplace atmosphere and relationship with their colleagues, as well as by the dynamic working conditions. Employees are not very satisfied by the career development opportunities and pay and social benefits offered.

\begin{tabular}{|c|c|c|c|c|c|c|}
\hline \multicolumn{7}{|c|}{ Table 1: Job Satisfaction } \\
\hline & $\begin{array}{c}\text { Overall } \\
\text { Satisfaction }\end{array}$ & $\begin{array}{c}\text { Pay and Social } \\
\text { Benefits }\end{array}$ & $\begin{array}{c}\text { Career Dev. } \\
\text { Opportunities }\end{array}$ & $\begin{array}{c}\text { Nature of } \\
\text { Work }\end{array}$ & $\begin{array}{c}\text { Atmosphere, } \\
\text { Team Spirit }\end{array}$ & $\begin{array}{c}\text { Dynamic } \\
\text { Working Cond. }\end{array}$ \\
\hline Mean & 3.79 & 3.33 & 3.28 & 3.87 & 4.18 & 3.99 \\
\hline Std Dev & .803 & .865 & 1.072 & .848 & .629 & .804 \\
\hline Source: Author
\end{tabular}

The self-assessment of the overall job satisfaction of the respondents is relatively high $-\mathrm{M}=3.79, \mathrm{SD}$ $=.803$ on a 5-point Likert scale. Additionally, $59.5 \%$ of the employees define themselves as satisfied, $14.3 \%$ as very satisfied, $19.8 \%$ chose the average level - neither satisfied nor dissatisfied. Only $4.8 \%$ of the employees state that they are dissatisfied with their job and barely $1.6 \%$ evaluate themselves as very dissatisfied.

The result of the one-dimensional satisfaction analysis shows that almost $75 \%$ of the respondents are satisfied with their job and only 5.4\% are dissatisfied, which confirms the second research hypothesis that "most IT employees in the subject group define themselves as satisfied with their work."

When determining their individual performance through the seven different elements, most of the IT employees in the sample evaluate their own performance above the average level in all categories:

\begin{tabular}{|c|c|c|c|c|c|c|c|}
\hline \multicolumn{8}{|c|}{ Descriptive Statistics } \\
\hline & $\begin{array}{l}\text { Quality of } \\
\text { Work }\end{array}$ & Effectivenes: & Productivity & $\begin{array}{c}\text { Organisational. } \\
\text { Value }\end{array}$ & Proactivenes: & $\begin{array}{c}\text { Overall } \\
\text { Performance }\end{array}$ & $\begin{array}{c}\text { Manager } \\
\text { Assessment }\end{array}$ \\
\hline Mean & 4.03 & 3.91 & 3.89 & 3.83 & 3.92 & 4.02 & 3.81 \\
\hline Std Dev & .606 & .704 & 707 & 760 & .864 & .586 & 666 \\
\hline
\end{tabular}

Although all mean scores are above 3.80, the highest mean is observed in self-assessing the quality of one's work and the overall personal performance (values above 4 on a 5-point scale). The mean scores for productivity, effectiveness and proactiveness are almost equal (3.89, 3.91 and 3.92 points, respectively). There is a slightly lower mean value of 3.83 in the self-assessment of the contributed organizational value.

\section{Job Satisfaction Mean Levels among the Different Demographic Groups}

A one-way ANOVA test was used to check how the average job satisfaction means differ among the different employees, based on their gender, age, level of education and years in the current position. For the purposes of this test, a new variable, "average job satisfaction", was created, representing the average satisfaction score of the five individual factors and the overall job satisfaction. A Shapiro-Wilk test confirms data normality of the new variable, $\mathrm{W}(126)=0.98, \mathrm{p}=.12$ and also the homogeneity of variance requirement has been met in all one-way ANOVA examinations.

The one-way ANOVA test shows no statistically significant difference between the average job satisfaction mean levels among the different employee groups, based on their age and level of education. The respective results are $\mathrm{F}(3,122)=1.36, \mathrm{p}=.259$ for age and $\mathrm{F}(2,123)=2.01, \mathrm{p}=.138$ for education. Contrary to the initial expectations, there is a statistically significant difference between the average job satisfaction mean levels of employee groups, based on their gender and years in the current position.

The mean average job satisfaction of males $(\mathrm{M}=3.82, \mathrm{SD}=.635)$ is slightly higher than the value for females $(\mathrm{M}=3.57, \mathrm{SD}=.552)$, which suggests that males in the examined sample are generally more satisfied with their jobs. 


\begin{tabular}{|c|c|c|c|c|c|}
\hline \multirow[t]{2}{*}{ Average Job Satisfaction } & \multicolumn{5}{|c|}{ ANOVA } \\
\hline & Sum of Squares & $\mathrm{df}$ & Mean Square & $\mathrm{F}$ & Sig. \\
\hline Between Groups & 1.711 & 1 & 1.711 & 4.628 & .033 \\
\hline Within Groups & 45.854 & 124 & .370 & & \\
\hline Total & 47.566 & 125 & & & \\
\hline
\end{tabular}

In relation to the years in the current position, results are as follows:

\begin{tabular}{|l|l|c|c|c|c|}
\hline \multicolumn{5}{|l|}{ Table 4: One-way ANOVA: Average Job Satisfaction - Years in the Current Position } \\
\hline Average Job Satisfaction & Sum of Squares & df & Mean Square & F & Sig. \\
\hline & 4.188 & 4 & 1.047 & 2.921 & .024 \\
\hline Between Groups & 43.377 & 121 & .358 & & \\
\hline Within Groups & 47.566 & 125 & & & \\
\hline Total &
\end{tabular}

Source: Author

After applying a Tukey post hoc test, it was possible to determine that a statistically significant difference in the mean average job satisfaction value exists only between employees working in their current position between 8 and 11 years and employees working between 12 and 15 years. Employees in the group 12-15 years report substantially higher average job satisfaction in their current position (M $=4.10, \mathrm{SD}=.487)$ than those in the group $8-11$ years $(\mathrm{M}=3.53, \mathrm{SD}=.725)$.

Based on the one-way ANOVA results, hypothesis $3(\mathrm{H} 3)$, which states that "the average job satisfaction levels of IT employees do not differ significantly, based on their gender, age, level of education and years in the current position." is confirmed for employee groups, based on age and level of education, but rejected for gender and years in the current position.

Correlation Analysis

Proceeding the correlation analysis, Cronbach's alpha was used to check the reliability and internal consistency of the set of questions examining job satisfaction and individual performance. The tests confirm that all 16 statements that measure employee job satisfaction were adequately chosen and have an excellent internal consistency $(\alpha=.900)$. Likewise, the 7 questions that measure individual performance show high internal consistency $(\alpha=.864)$. Furthermore, removing any of the questions in the two sets does not lead to a significantly increased alpha coefficient. These results confirm the general reliability of the scale.

The main research hypothesis is examined through a correlation analysis. To test the relationship between job satisfaction and personal performance, two average variables are utilized -1) average job satisfaction, represented as the average satisfaction score of the five individual factors and the overall job satisfaction and 2) average individual performance, represented by the average score of the seven performance questions examined in the questionnaire. The new variables have the following means and standard deviations: $\mathrm{M}=3.73, \mathrm{SD}=.617$ for average job satisfaction and $\mathrm{M}=3.92, \mathrm{SD}=.803$ for average performance.

The Shapiro-Wilk test was used to check the normality of the two variables, and the results showed that average job satisfaction is normally distributed while average performance does not meet the normality criteria.

\begin{tabular}{|l|c|c|c|}
\hline \multicolumn{4}{|c|}{ Table 5: Tests of Normality } \\
\hline & Shapiro-Wilk & Sig. \\
\hline & Statistic & df & .120 \\
\hline Average Job Satisfaction & .983 & 126 & .046 \\
\hline Average Performance & .979 & 126 & \\
\hline Source: Author & \multicolumn{3}{|c|}{}
\end{tabular}

To compensate for the normal distribution limitation, Spearman's rank-order nonparametric correlation was chosen to check the relationship between job satisfaction and personal performance. The correlation analysis result shows a significant moderate positive correlation between average satisfaction and average individual performance. 


\begin{tabular}{|l|l|c|c|}
\hline \multicolumn{3}{|c|}{ Table 6: Examining the Correlation between Job Satisfaction and Personal Performance } \\
\hline \multicolumn{3}{|c|}{ Spearman's Rho Correlation } \\
\hline \multirow{4}{*}{ Average Job Satisfaction } & Correlation Coefficient & Average Job Satisfaction & Average Performance \\
\cline { 2 - 4 } & Sig. (2-tailed) & 1 & $.381^{* *}$ \\
\cline { 2 - 4 } & $\mathrm{N}$ & .000 \\
\hline \multirow{4}{*}{ Average Performance } & Correlation Coefficient & $.381 * *$ & 126 \\
\cline { 2 - 4 } & Sig. (2-tailed) & .000 & 126 \\
\cline { 2 - 4 } & $\mathrm{N}$ & 126 \\
\hline$* *$ Correlation is significant at the 0.01 level (2-tailed). \\
\hline
\end{tabular}

The result of the correlation analysis confirms the main research hypothesis, which states that "the job satisfaction of employees in the IT sector is positively related to their individual performance in the workplace." This result further confirms the results of the meta-analysis conducted by Judge et al. (2001) presented earlier in this paper.

\section{Conclusion}

\section{Main Results}

After an extensive literature review and analysis of a number of empirical studies that examine job satisfaction and after conducting personal research among 126 IT employees, it was found that there is a positive correlation between employees' satisfaction and their individual performance, which is moderate in value, with bidirectional influence and, most likely, dependent on some additional factors, unexplored in the current study. This result further confirms the position of the authors, who claim that there is a positive relationship between job satisfaction and performance.

Based on these results, it can be assumed that employees who like the nature of their job and are satisfied by the pay level, the career development opportunities, the dynamic working conditions and the relationships with their colleagues will most probably do better in the workplace and are likely to be more efficient, productive and initiative and will generally contribute to higher organizational value.

Additionally, it was revealed that almost $75 \%$ of the IT employees who participated in the survey define themselves as satisfied with their job. Regarding job satisfaction mean levels, the results of the study show no significant difference, based on employee's age and level of education. Surprisingly, it appeared that there is a statistically significant difference between the mean job satisfaction levels, based on employees' gender and years in the current position. Males show slightly higher average job satisfaction than females. Also, employees who worked in their current position between 12 and 15 years appear to be more satisfied than those who worked between 8 and 11 years.

\section{Limitations}

The study has three main limitations -1$)$ relatively small sample size $(\mathrm{N}=126), 2)$ most of the respondents (64.8\%) work in one international company, and 3) most of the employees (72.2\%) work in Bulgaria. This may cause some deviation in the results, and the present study may not be fully representative of the IT sector in general. To achieve more widely valid results, drive broader conclusions and isolate to a greater extent the local influence, the results of the present study should be further verified among bigger samples, as well as among various companies from all over the world.

\section{Discussions}

Findings in the present study can be used as a basis for future research, which further examines the relationship between job satisfaction and performance in different organizational or regional contexts, as well as investigating the influence of different mediating variables like work engagement, motivation, stress or exhaustion. Additionally, the results about differences in average job satisfaction levels between genders and employees that have spent a different number of years in their current positions may be further investigated.

The focus on highly qualified staff and their long-term retention and development makes job satisfaction and personal performance some of the most relevant and strategic topics among companies in the IT industry. Confirming results from previous studies on the topic, the present research underlines the 
crucial importance of employee satisfaction level, which may positively impact their personal performance, which is characterized by increased efficiency, productivity, willingness to take on new initiatives, proactivity, improving the quality of work and organizational value. Therefore, employees' satisfaction and personal performance should be carefully evaluated and placed at the centre of organizational goals as factors that may lead to excellent business results and market leadership.

\section{Acknowledgements}

I gratefully thank the ScholarNet project for funding the publishing of the current article.

\section{References}

Bednarska, M., \& Szczyt, M. (2015). Variations in Job Satisfaction in Service Industries: Comparative International Analysis. Foresight, 17(6), 599-615. http://doi.org/10.1108/FS-08-2013-0037

Brayfield, A. H. \& Crockett. W. H. (1955). Employee Attitudes and Employee Performance. Psychological Bulletin. 52, $396-$ 424

Crespi-Vallbona, M., \& Mascarilla-Miró, O. (2018). Job Satisfaction. The Case of Information Technology (IT) Professionals in Spain. Universia Business Review, 58, 36-51 http://doi.org/10.3232/UBR.20I8.VI5.N2.02

Ćulibrk, J., Delić, M., Mitrović, S., \& Ćulibrk, D. (2018). Job Satisfaction, Organizational Commitment and Job Involvement: The Mediating Role of Job Involvement. Frontiers in Psychology, 9. https://doi.org/10.3389/fpsyg.2018.00132 Firth, L., Mellor, D. J., Moore, K. A., \& Loquet, C. (2004). How Can Managers Reduce Employee Intention to Quit? Journal of Managerial Psychology, 19(2), 170-187. https://doi.org/10.1108/02683940410526127

George, E., \& Zakkariya, K.A. (2015). Job Related Stress and Job Satisfaction: A Comparative Study among Bank Employees. Journal of Management Development, 34, 316-329. http://doi.org/10.1108/JMD-07-2013-0097

Herzberg, F., Mausner, B., Peterson, R. O., \& Capwell. D. F. (1957). Job attitudes: Review of research and opinion. Pittsburgh: Psychological Service of Pittsburgh.

Hoppock, R. (1935). Job Satisfaction. New York: Harper and Brothers.

Huang, K. P., \& Wang, K. Y. (2019). A Study on the Correlation between Working Pressure and Job Satisfaction from the Viewpoint of Work Exhaustion. Revista de Cercetare si Interventie Sociala, 64, 235-245. https://doi.org/10.33788/rcis.64.19

Ismail, A., \& Razak, M. R. (2016). A Study on Job Satisfaction as a Determinant of Job Motivation. Acta Universitatis Danubius. Economica, 12(3), 30-44.

Judge, T. A., Thoresen, C. J., Bono, J. E., \& Patton, G. K. (2001). The Job Satisfaction-Job Performance Relationship: A Qualitative and Quantitative Review. Psychological Bulletin, 127(3), 376-407. http://doi.org/10.1037/0033-2909.127.3.376

Kamalanabhan, T. J., Mayuri, D., \& Sai, L. P. (2009). Employee Engagement and Job Satisfaction in the Information Technology Industry. Psychological Reports. 105(3), 759-770. http://doi.org/10.2466/PR0.105.3.759-770

Locke, E. A. (1970). Job Satisfaction and Job Performance: A Theoretical Analysis. Organizational Behavior and Human Performance, 5, 484-500.

Martins Abelha, D., César Da Costa Carneiro, P., \& Cavazotte, F. (2018). Transformational Leadership and Job Satisfaction: Assessing the Influence of Organizational Contextual Factors and Individual Characteristics. Review of Business Management, 20(4), 516-532. https://doi.org/10.7819/rbgn.v0i0.3949

Moro, S., Ramos, R. F., \& Rita, P. (2020). What Drives Job Satisfaction in IT Companies? International Journal of Productivity and Performance Management, 70(2), 391-407. https://doi.org/10.1108/ijppm-03-2019-0124

Motowidlo, S. J., Borman, W. C., \& Schmit, M. J. (1997). A Theory of Individual Differences in Task and Contextual Performance. Human Performance, 10(2), 71-83. https://doi.org/10.1207/s15327043hup1002_1

Mount, M., Ilies, R., \& Johnson, E. (2006). Relationship of Personality Traits and Counterproductive Work Behaviors: The Mediating Effects of Job Satisfaction. Personnel Psychology, 59(3), 591-622. https://doi.org/10.1111/j.17446570.2006.00048.x

Organ, D. W. (1988). A Restatement of the Satisfaction-Performance Hypothesis. Journal of Management, 14(4), $547-557$. https://doi.org/10.1177/014920638801400405

Ostroff, C. (1992). The Relationship between Satisfaction, Attitudes and Performance: An Organizational Level Analysis. Journal of Applied Psychology, 77(6), 963-974. https://doi.org/10.1037/0021-9010.77.6.963

Platis, C., Reklitis, P., \& Zimeras, S. (2015). Relation between Job Satisfaction and Job Performance in Healthcare Services. Procedia - Social and Behavioral Sciences, 175, 480-487. https://doi.org/10.1016/j.sbspro.2015.01.1226

Schwab, D. P. \& Cummings, L. L. (1970). Theories of Performance and Satisfaction: A Review. Industrial Relations, 9, 408430

Spector, P. E. (1994). Job Satisfaction Survey. Retrieved from http://shell.cas.usf.edu/ pspector/scales/jsspag.html

Taba, M. I. (2018). Mediating Effect of Work Performance and Organizational Commitment in the Relationship between Reward System and Employees' Work Satisfaction. Journal of Management Development, 37(1), 65-75. https://doi.org/10.1108/JMD-11-2016-0256

Valaei, N., \& Rezaei, S. (2016). Job Satisfaction and Organizational Commitment: An Empirical Investigation among ICTSMEs. Management Research Review, 39, 1663-1694. https://doi.org/10.1108/MRR-09-2015-0216

Vroom, V. H. (1964). Work and Motivation. NewYork: John Wiley and Sons. 